\title{
Detection of Staphylococcus aureus's Strain Similarity on Surgical Ward Nurses's Hand and Nose and Post Operative Wound Infection Using Coa Gene Through PCR-RFLP Method
}

\author{
Fauzia Andrini ${ }^{1}$, Imam Supardi ${ }^{2}$,Sunarjati Sudigdoadi ${ }^{3}$, Sadeli Masria ${ }^{4}$
}

\begin{abstract}
Staphylococcus aureus (S.aureus) remains to be the most important cause of post operative wound infection. Nurses could become reservoirs to transmit S.aureus through contaminated hands transiently, or through colonized nose. Strain polymorphism could be determined by Restriction Fragment Length Polymorphism (RFLP), using coa gene and restriction endonuclease enzyme Alu1. There were 30 isolates of S.aureus's infection, and 20 isolates taken from hands and nose of the nurses in charge. From 50 isolate positive S.aureus, PCR results showed single and multiple bands within 300 to 900 base pairs (bp) in length, and multiple bands within 200 to $600 \mathrm{bp}$. Five out of 30 patients (17\%) showed no PCR-RFLP similarity with any of the nurses. Ten out of 15 nurses which hands were positive for S.aureus, has PCR-RFLP similarity with some patients. There was only 1 out of 5 nurses which nose was positive for S.aureus, showed PCR-RFLP similarity with some patients. Statistically, the proportion of the similar PCR-RFLP between those samples in this study is 0.12 (12\%). Conclusion: Nurses had $12 \%$ PCR-RFLP similarity for S.aureus with post operative wound infection.
\end{abstract}

Keywords: post operative wound infection, similarity of strain, S.aureus, coa gene, PCR-RFLP

Among different types of nosocomial infection, post-operative wound infection occurs most frequently, with a rate of $8-17 \%$ of overall infection rate in hospitals in developed countries. ${ }^{1,2}$ National Nosocomial Infections Surveillance (NNIS), Central of Diasease Control (CDC), reported that S. aureus with negative coagulation Staphylococcus and Enterococcus consist of $34 \%$ of overall nosocomial infection rate in developed countries. ${ }^{1}$ In this group, $S$. aureus is the major cause of post-operation wound infection, with $19 \%$ out of $56 \%$ occurrence of postoperative wound infection. ${ }^{2}$

Post-operative wound infection reservoir could occur in human or contaminated objects. ${ }^{1,2,4}$ This reservoir determines nosocomial infection transmission modes:

Coresponding Author: Department of Microbiology Medical Faculty Riau University Pekanbaru Riau Indonesia, Email:fauzia.andrini@gmail.com

2,3,4 Department of Microbiology Medical Faculty Padjadjaran University Bandung Indonesia
1. Through direct contact: i.e. from medical staff to the patients, from patients to patients, or from visitors to patients.

2. Through indirect contact: i.e. from contaminated objects or hospital ventilation system ${ }^{1}$.

Nurses could transmit organism through direct contact to the patients, particularly during medical treatment. In $S$. aureus post-operative wound infection, transmission happened through contaminated hands transiently or through contaminated nose. ${ }^{1,4}$ The transmission occurs after contact with infected patients, contact with contaminated equipments, or contact with carriers. ${ }^{2,4}$

In epidemiology, it is important to determine the reservoir or modes of transmission and this requires various laboratory examinations that determine similarities among different infectioncausing strains. ${ }^{4}$ In order to determine strain similarities, it is necessary to conduct an examination with highly accurate differentiation or strong polymorphism, which only can be performed through genotypic molecular examination. ${ }^{4,7}$ 
Polymorphism may occurs from mutation and causes difference in single property. However, it does not affect genetic production ${ }^{8}$. RFLP (restriction fragment length polymorphism) 9,10 determines variation of a species and differentiated various strains, which is conducted through polymerase chain reaction (PCR) to determine the microorganism types at genetic level which is fast, easily available and affordable. $5,7,10,12,13,14,15,16$

The PCR-RFLP method utilizes chromosomal genes. In the case of $S$. aureus, this method utilizes the coa gene that code protein coagulation. The coa gene are the genetic marker with slow evolutionary process and possess repeating regio-polymorphic, which differentiate $S$. aureus strain. This gene is also an important virulence factor and has been utilised as epidemiology marker in S. aureus. ${ }^{12,16,18}$ Genetic sequencing analysis of coa gene shows regio polymorphic that ends at 3 ' end coding region, and this region contains 81 bp tandem Short Sequence Repeat (SSR) with variable number and sequence. By determining the size and site of its restriction, this method can be utilised to analyse PCR-RFLP S.aureus. ${ }^{11,14,15,17} \mathrm{~A}$ restriction endonuclease enzyme that works best in giving the depiction of polymorphism is Alu1..$^{11,14,15}$

Nurses are an important component in transmission of S. aureus post-operative wound nosocomial infection. This can be further investigated through PCR-RFLP profile through coa gene examination, in order to detect the strain similarities. It is important that nurses are well informed about the potentials of bacterial reservoir in order to be more vigilant in handling the patients.

\section{METHODS}

The subject of this research is the speciment from the hands and nose of the nurses from third class male surgery ward, as well as speciments from the post-operative wound infection from patients in the third class male surgery ward at Hasan Sadikin General Hospital in Bandung Indonesia. Both patients and nurses must fulfill the criteria for inclusion. According to the statistical requirements, the sample number must be at least thirty patients. The number of nurses is according to the ones who take care of the patients, and must fulfill the critera for nurse's inclusion, and hence twenty nurses are taken as samples. In this study, hand'swab before nurses did the handwashing procedure had not been taken.

The method of this research is cross-sectional with proportion testing analysis.

\section{Identification of $S$. aureus Using Conventional Method}

The speciment used is swab taken from the hands and nose of the nurses after hand-washing, and post-operative wound infection in the patients. Examination are done through microsopic Gram stain, culture, and identification of colony in the blood agar plate, catalase examination, and slide coagulation test. If the coagulation slide test result is negative, subsequent tube coagulation test is conducted.

Identification of S. aureus Using Molecular Method

A subsequent molecular examination is done in each speciment with positive $S$. Aureus result. For each isolated $S$. aureus samples the following method is conducted:

\section{- DNA Isolation}

After culturing in Luria Bertani broth, DNA isolation is conducted using Wizard Genomic DNA Purification Kit from Promega, which consists of EDTA $50 \mathrm{mM} \mathrm{pH} \mathrm{8.0,} \mathrm{Lysozyme} 10 \mathrm{mg} / \mathrm{mL}$, Isopropanol, Ethanol 70\%, nuclei lysis solution, protein precipitation solution, DNA rehidration solution

\section{- PCR Amplification of coa gene}

PCR Primer design for coa gene uses basic nucleotides with access No X16457 $7^{14,24}$. Forward primer 5' ATA GAG ATG CTG GTA CAG G3' and reverse primer 5'GCT TCC GAT TGT TCG ATG C3' are used. Each amplification process is done in sterile eppendorf tube, in which each reaction consists of DNA template $3 \mathrm{i} \mathrm{L}$ and $0,5 \mathrm{iL}$ for each 
of the primer, buffer 2,5 ì, Mg2+ $3 \mathrm{iL}, \mathrm{dNTP} 0,5$ ì , Taq polymerase $0,125 \mathrm{iL}$, and ddH2O $14,9 \mathrm{iL}$ to achieve the final volume of $25 \mathrm{iL}$. Thermalcycler is used with PCR condition of $94{ }^{\circ} \mathrm{C}$ initial denaturation for two minutes. A 30-cycle amplification is conducted with $94^{\circ} \mathrm{C}$ denaturation for one minute, annealing $42^{\circ} \mathrm{C}$ for one minute, and elongation $72^{\circ} \mathrm{C}$ for one minute. Subsequently, a post-elongation procedure is done with $72{ }^{\circ} \mathrm{C}$ for 10 minutes and storage in $4^{\circ} \mathrm{C}$. PCR product measurement ( $5 \mathrm{ì} \mathrm{L}$ aliquot) is determined through $100 \mathrm{bp}$ ladder marker comparison in agarose gel electrophoresis of $2 \%$.

\section{- Endonuclease DNA restriction analysis in coa gene resulting from PCR amplification}

The PCR products are purified through sedimentation in ethanol precipitation, and agarose gel electrophoreses is conducted to approximate DNA concentration by comparing it with PUC19/ Hindf1 marker. Approximately 800 ng (15-20 iL) of PCR product is cut with $0.1 \mathrm{U}$ restriction endonuclease enzymes Alul and placed in $1.5 \mathrm{~mL}$ sterile tubes and stored for one day in water bath of $37^{\circ} \mathrm{C}$. Ten ì $\mathrm{L}$ restricted PCR products are analysed through agarose gel electrophoresis in order to obtain RFLP mapping.

\section{- Data Analysis}

For each patient with similar PCR-RFLP mapping with the nurses, identification and subsequent proportion test analysis are conducted

\section{RESULT}

The research is done from June to November 2005.

\section{- Patient and Nurse Characteristics}

There are $86(32 \%)$ patients with post-operative wound infection from a total of 269 patients during the course of the study. From all the infected patients, $35 \%$ is caused by S. aureus, with $20 \%$ from general surgery and $15 \%$ from orthopaedic surgery. Additionally, there are 20 nurses positively affected with $S$. aureus from a total of 26 nurses. Among the 20 nurses, $19 \%$ has positive nasal $S$. aureus, while $58 \%$ has from hands. There is no nurse with positive $S$. aureus in both hands and nose.

\section{- PCR-RFLP Pattern}

There are a total $50 \mathrm{~S}$. aureus isolates, consisting 30 patients isolates and 20 nurses isolates. The isolates resulted in PCR product (with exception of strain S.epidermidis ATCC 12228 as negative control) with varied sizes between $100 \mathrm{bp}$ to 2000 bp. The Alu1 restriction resulted in single or multiple DNA fragments. (Figure $1 \mathrm{~A}$ dan B).

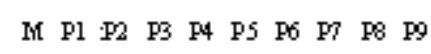

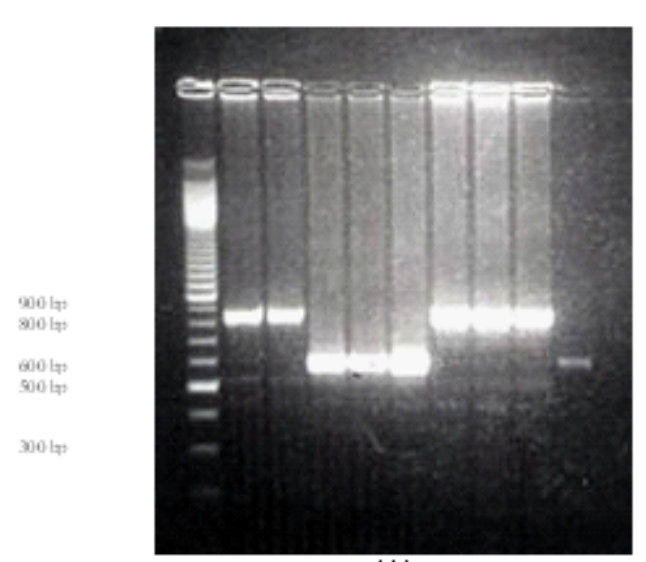

(A)

M P1 P2 P3 P4 P5 P6 F7 P8 P9 +

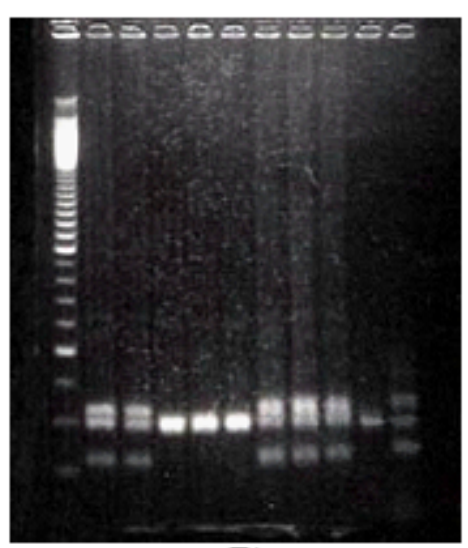

(B)

Figure 1

PCR-RFLP Coa Gene mapping with restriction endonuclease enzyme Alul in 9 patients. (A) PCR results before restriction. (B) After restriction (RFLP). $\mathrm{M}=$ Marker 100 bp ladder $; \mathrm{P}=$ patients; - = negative controls; $+=$ positive controls 
There are seven PCR product pattern, and there are 12 resulting PCR-RFLP mapping with most pattern is found in 15 samples with single-band PCR (nearing $600 \mathrm{bp}$ ) and single-band RFLP (nearing 300 bp)

\section{PCR-RFLP Mapping in Patient and Nurse}

From 30 Patients, five (15\%) did not show similarity of PCR-RFLP mapping with any nurse. Moreover, among the nurses with positive $S$. aureus in their hands, ten nurses has similar PCR-RFLP mapping with their patients. Additionally, among the five nurses with positve $S$. aureus in their noses, only one nurse has similar PCR-RFLP mapping with the patients (Figure $2 \mathrm{~A}$ and $\mathrm{B}$ )

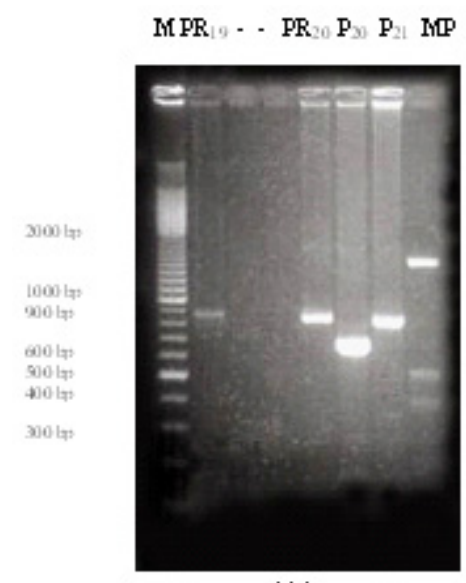

(A)

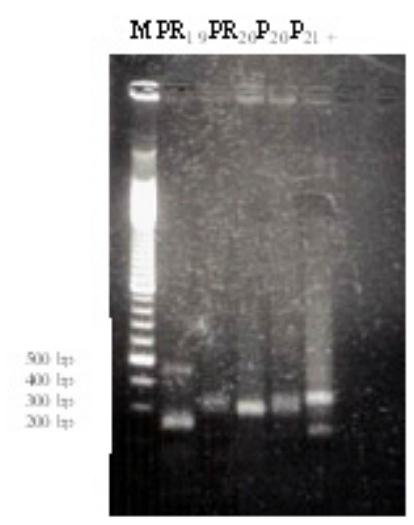

(B)

Figure 2 PCR-RFLP coa gene mapping with restriction endonuclease enzyme Alul in 2 patients (P) and 1 nurse (PR). (A) PCR results before restriction: Marker $100 \mathrm{bp}$ ladder, PR19, - control, - control, PR20, P20, P21, Marker PUC19/Hindf1. (B) After restriction : Marker 100 bp ladder, PR19, PR20, P20, P21, + control.

Post-Operative Wound Infection Analysis and S.aureus Detection in Patients

S.Aureus causes post-operative wound infection in $35 \%$ of patients from the total of post-operative wound infection cases (20\% general surgery cases and $15 \%$ orthopaedic surgery cases). Djojosugito 1989 reported that S.aureus is the main cause of post-operative wound infection, among the positive gram bacteria group (16.5\% general surgery and 25.3 $\%$ orthopaedic surgery) ${ }^{3}$, and this research shows an increase in general surgery infection rate, but a declining in orthopaedic surgery infection rate.

\section{Analysis of S.aureus Detection in Nurses}

Five nurses (19\% of total nurse) are positive S.aureus in the nasal area while fifteen nurses (58\%) are positive in the hands. This result shows ineffectiveness in hand washing procedure prior to wound treatment in decreasing S.aureus colonization rate. This research supported previous research by Roosyati $1998^{6}$, in which most S.aureus is found in the hand area of the nurses $(9.3 \%)$.

\section{Analysis of PCR-RFLP Pattern}

Several PCR result shows multiple PCR product, and this shows different result from the research of Hookey et. al ${ }^{14}$, in which all isolates reveals single PCR product. However, this research shows similarity to Goh et.al ${ }^{15}$, in which many isolates resulted in multiple PCR product.

Twelve PCR-RFLP patterns from restriction result of 7 PCR patterns shows that the Alul enzyme can differentiate S.aureus strains, and this supports both Hookey et.al ${ }^{14}$ and Goh et.al ${ }^{15}$.

\section{Statistical Analysis}

Based on the PCR-RFLP mapping of both the patients and the nurses, we can obtain the proportion result and its average. The average proportion is $12 \%$ 
for 30 patients with similar PCR-RFLP mapping with their nurses.

The test for significance shows that $\mathrm{H}_{0}$ is not rejected since $t$ count $<\mathrm{t}$ table. This means that the similarity of PCR-RFLP mapping in S.aureus isolates obtained from the hands and noses of the nurses and the ones obtained from the patients is less than $50 \%$.

\section{PCR-RFLP Analysis in Patient and Nurses}

Most nurses who have similar PCR-RFLP mapping with the patients positively have S.aureus in their hands. Although the nurses has performed hand-washing each time they begin to treat different patients, it seems that this procedure has not been effective in preventing S.aureus transmission.

Proportion test analysis and its significance show that nurses with similar PCR-RFLP mapping with the patients is $12 \%$ (with average proportion less than 50\%). Therefore, from 20 nurses with positive S.aureus (58\% in the hand area and $19 \%$ in nasal area), only $12 \%$ has similar PCR-RFLP mapping with post-operative wound infection which was caused by S.aureus.

Seven patients has similar PCR-RFLP mapping with nurse 3 . This means that the nasal area of nurse 3 tend to become carrier that contracts S.aureus infection, and this conforms with the theory stating that the nasal area of the hospital worker potentially act as transmission base of S.aureus to the patient.

Besides, based on the available data, there are three patients in the same ward with adjacent beds, and all had post-operative wound infection on the third day after opening the wound covering. While the PCR-RFLP mapping of all the three patients are not the same, no similar PCR-RFLP mapping with the nurse is found. Therefore, the infection in the three patients may have occurred from other carrier such as contaminated operating instrument, etc.

Sample from one nurse shows similar PCRRFLP mapping with five patients. Based on the available data, three out of five of the patients are in the same ward with adjacent beds, and the three patients had post-operative wound infection on the fourth day after opening the wound covering. This means that the hand-washing procedure conducted by the nurse has not been effective and S.aureus was transmitted to the patient through the nurse's hand.

This research does not prove the actual transmission direction, whether it occurred from the patient to the nurse or vice versa. The available data only shows similarity of PCR-RFLP between the S.aureus strain found in the nurse and in the patient.

\section{CONCLUSION}

The nurse has $12 \%$ similarity in PCR-RFLP mapping with the patient. For further research, it may be necessary to examine other possible S.aureus post-operative wound infection transmission sources with PCR-RFLP method using coa gene in order to find similarities between the different sources.

\section{ACKNOWLEDGMENT}

We would like to express her appreciation to Prof. Dr.Ridad Agoes., dr., MPH., DAPE for his critical reading of the manuscript.

\section{REFERENCES}

1. Tortora GJ, Funke BR, Case CL. Principles of disease and epidemiology. In Microbiology an introduction. $8^{\text {th }}$ ed. San Fransisco : Pearson Education Inc, 2004: 408-31.

2. Mims C, Dockrell HM, Goering RV, Roitt I, Wakelin D, Zuckerman M. $3^{\text {rd }}$ ed. Edinburgh : Mosby , 2004 : 545-66.

3. Djojosugito MA. Mikrobiologi infeksi luka operasi nosokomial dan penggunaan antibiotika rasional. Bandung : Fakultas Kedokteran Universitas Indonesia dan Yayasan Pengabdian, 1996

4. Herwaldt LA, Wenzel RP. Dynamics of hospitalacquired infection. In : Murray PR, editor. Manual of clinical microbiology. $6^{\text {th }}$ ed. Washington DC : American Society for Microbiology Press, 1995 : 169-76.

5. McGowan JE, Metchock B. Infection control epidemiology and clinical microbiology. In Murray PR, editor. Manual of clinical 
microbiology. $6^{\text {th }}$ ed. Washington : American Society for Microbiology Press, 1995: 182-88.

6. Roosyati OF. Deteksi Staphylococcus aureus resisten metisilin (MRSA) pada tangan, hidung dan tenggorok perawat di bagian perawatan bedah RSUP Dr.Hasan Sadikin Bandung (Tesis). Bandung : Universitas Padjajaran, 1998

7. Forbes BA, Sahm DF, Weissfeld AS. Molecular methods for microbial identification and characterization. In Bailey \& Scott's diagnostic microbiology. $11^{\text {th }}$ ed. St. Louis : Mosby, 2002: $169-88$.

8. Glick BR, Pasternak, JJ. Human molecular genetics. In Molecular biotechnology principles and applications of recombinant DNA. $3^{\text {rd }}$ ed. Washington DC : American Society for Microbiology Press , 2003: 633-69.

9. Doorn L. Mutation detection PCR-based approaches. In Persing DH, editor. Molecular microbiology diagnostic principles and practice. Washington DC: American Society for Microbiology Press , 2004 : 145-49.

10.Snyder L, Champness W. Recombinant DNA techniques and cloning bacterial genes. In Molecular genetics of bacteria. Washington, DC : American Society for Microbiology Press, 1997: 393-420.

11.Bannerman TL, Hancock GA, Tenover FC, Miller JM. Pulsed-field gel electrophoresis as replacement for bacteriophage typing of Staphylococcus aureus. Journal of Clinical Microbiology. 1995 ; 33 : 551-5

12.Montesinos I, Salido E, Delgado T, Cuervo M, Sierra A. Epidemiologic genotyping of methicillin-resistant Staphylococcus aureus by pulsed-field gel electrophoresis at a university hospital and comparison with antibiotyping and protein A and coagulase gene polymorphisms. Journal of Clinical Microbiology. $2002 ; 40$ : 2119-25

13.Stranden A, Frei R, Widmer AF. Molecular typing of methicillin- resistant Staphylococcus aureus can PCR replace pulsed field gel electrophoresis ?. Journal of Clinical Microbiology. 2003 ; 41 : 3181-86.
14.Hookey JV, Richardson JF, Cookson BD. Molecular typing of Staphylococcus aureus on PCR restriction fragment length polymorphism and DNA sequence analysis of coagulase gene. Journal of Clinical Microbiology. 1998 ; 36 : $1083-89$

15.Goh S, Byrne SK, Zhang CL, Chow AW. Molecular typing of Staphylococcus aureus on the basis of coagulase gene polymorphisms. Journal of Clinical Microbiology. 1992 ; 30 : $1642-45$

16. Hartstein AI, Morrthland VH, Eng S, Archer GL, Schoenknecht FD, Rasad AL. Restriction enzyme analysis of plasmid DNA and bacteriophage typing paired Staphylococcus aureus blood culture isolates. Journal of Clinical Microbiology. 1989 ; 27 : 1874-79.

17. Shopsin B, Gomez M, Waddington M, Riehman $\mathrm{M}$, Kreiswirth BN. Use of coagulase gene (coa) repeat region nucleotide sequences for typing of methicillin-resistant Staphylococcus aureus strains. Journal of Clinical Microbiology. 2000 ; $38: 3453-56$

18. Arbeit RD. Laboratory procedures for the epidemiologic analysis of microorganisms. In Murray PR, editor. Manual of clinical microbiology. $6^{\text {th }}$ ed. Washington : American Society for Microbiology Press , 1995 :190-204.

19.Cappuccino JG, Sherman N. Identification of human staphylococcal patogens.In Microbiology a laboratory manual. $6^{\text {th }}$ ed. San Fransisco : Benjamin Cummings, 2001 : 383-87.

20. Salyers AA, Whitt DD. Bacterial Pathogenesis a molecular approach. $2^{\text {nd }}$ ed. Washington, DC : American Society for Microbiology, 2002 : 216 $-31$

21.Ryan KJ. Staphylococci. In Ryan KJ, Ray CG, editors. Sherris medical microbiology an introduction to infectious diseases. $4^{\text {th }}$ ed. New York : McGraw Hill Medical Publishing Division, 2004 : 261 - 271

22.Brooks GF, Butel JS, Morse SA. The Staphylococci.In Jawetz, Melnick, \&Adelberg's Medical microbiology international edition. $23^{\text {rd }}$ ed. New York : McGraw Hill, 2004 : 223 - 228 
23. Ryan KJ. Nosocomial infections and infection control. In Ryan KJ, Ray CG, editors. Sherris medical microbiology an introduction to infectious diseases. $4^{\text {th }}$ ed. New York: McGrawHill Medical Publishing Division, 2004 : 91521.

24.Staphylococcus aureus gene for staphylocoagulase sequence. Access number X16457 (cited 2004 Dec 29). Available from : http://www.ncbi.nlm.nih.gov/entrez/viewer . fegi $? \backslash d b=$ nucleotide $\& \mathrm{val}=46736$

25.Micklos DA, Freyer GA, Crotty DA. DNA Science a first course. $2^{\text {nd }}$ ed. New York : Cold Spring Harbor Laboratory Press, 2003 : 108 $15,341-74$.

26.Preissner KT, Chhatwal GS. Extracellular matrix and host cell surfaces : potential sites of pathogen interaction. In Cossart P, Boquet P, Normark S, Rappuoli R, editors. Cellular microbiology. $2^{\text {nd }}$ ed. Washington,DC : American Society for Microbiology Press, 2005 : 87-103.

27.Rademaker JLW, Savelkoul P. PCR amplification-based microbial typing. In Persing $\mathrm{DH}$, editor. Molecular microbiology diagnostic principles and practice. Washington, DC : American Society for Microbiology Press , 2004: 197-214.

28.Hiramatsu K, Kuroda M, Baba T, Ito T, Okuma K. Application of genomic information to diagnosis, management, and control of bacterial infection : Staphylococcus aureus model. In Persing DH, editor. Molecular microbiology diagnostic principles and practice. Washington : American Society for Microbiology Press , 2004: 407-17.

29.Koneman EW, Allen SD, Janda WM, Schreckenberger PC, Winn WC. Basic bacteriology, concepts of virulence, and technologic advances in clinical microbiology : an overview. In Color atlas and textbook of diagnostic microbiology. $5^{\text {th }}$ ed. Philadephia, PA: Lippincott Williams \& Wilkins, 1997 : 1-58.

30.Koneman EW, Allen SD, Janda WM, Schreckenberger PC, Winn WC. The grampositive cocci : part I : staphylococci and related organisms. In Color atlas and textbook of diagnostic microbiology. $5^{\text {th }}$ ed. Philadephia, PA : Lippincott Williams \& Wilkins , 1997: 539-66.

31.Castiglia M, Smego RA. Skin and soft-tissue infections. In Mahon CR, Manuselis G, editors. Textbook of diagnostic microbiology. Philadelphia : W.B Saunders Company , 1995 : 870-91.

32.Neidhardt FC. Bacterial genetics. In Ryan KJ, Ray CG, editors. Sherris medical microbiology an introduction to infectious diseases. $4^{\text {th }}$ ed. New York: McGraw- Hill Medical Publishing Division , 2004 : 53-75. 